\title{
A Postcolonial Representation of Maria Edgeworth's Castle Rackrent and The Absentee
}

\author{
Dr. Hazmah Ali AI-Harshan
}

\author{
Assistant Professor at the Department of Languages and \\ Translation, Faculty of Education and Arts, University of \\ Tabuk, Saudi Arabia.
}

\begin{abstract}
In the tradition of the Big House fiction, Maria Edgeworth's Castle Rackrent and The Absentee explore the effect of the AngloIrish protestant Ascendancy as it governed and misgoverned Ireland. Edgeworth illustrates the tradition of the Big House as a symbol of both a personal and historical theme. This paper provides a reading of Castle Rackrent and The Absentee from a post-Colonial perspective. The paper maintains that Edgeworth's novel contain elements of a radical critique of the colonialist enterprise. The significance of Castle Rackrent lies mainly in the fact that is the first English novel to speak in the voice of the colonized Irish. The matrimonial plot in The Absentee functions as an imperial plot, constructing Ireland as a complementary but ever unequal partner in the family of Great Britain. This imperial marriage works hegemonically to produce the domestic stability considered so crucial to national and colonial stability. The Absentee explains more purposely how familial reorganization is dependent on the restitution of masculine authority and advantage, particularly for Irish community.
\end{abstract}

Keywords:

Maria Edgeworth, Castle Rackrent, The Absentee, The Big House fiction, Postcolonial Theory. 
(ISSN : 2536 - 9555)

\section{قراءة- من منظور ما بعد الاستعمار - لـروايتي قلعة راكنرينت

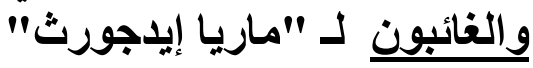

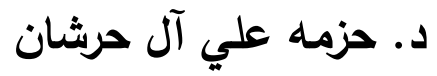

أستاذ مساعد الأدب الأجليزي، قسم آلئل حرثات والترجمة،

كلية الآداب، جامعة تبوك الأليز

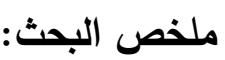

تقدم هذه الورقة البشثية قراءة من منظور ما بعد الاستعمار ل لروايتي قلعة

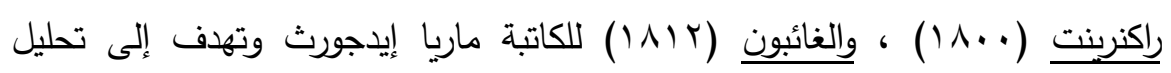

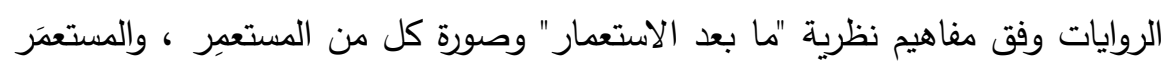

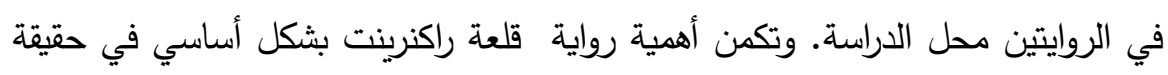

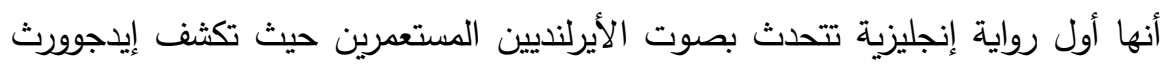

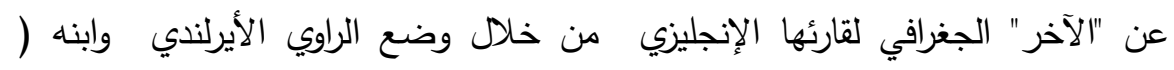

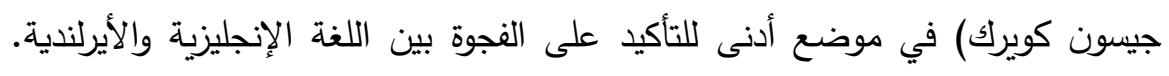

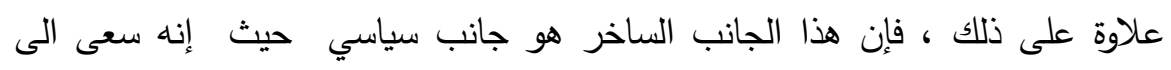

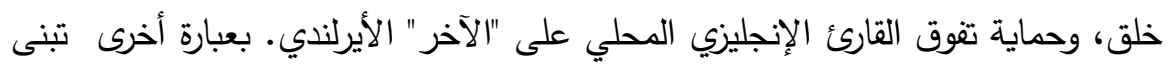

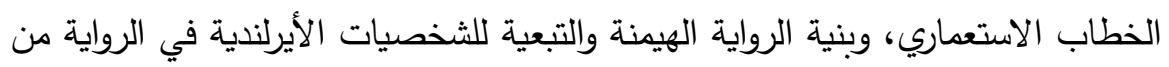

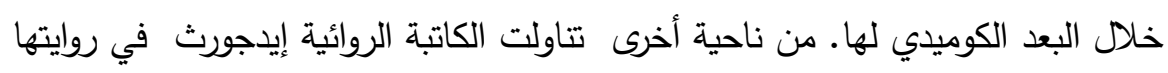

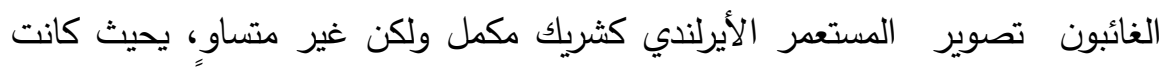

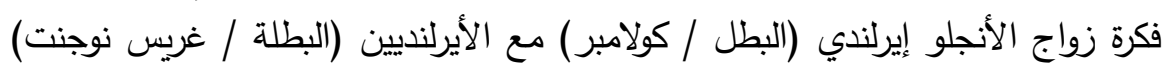

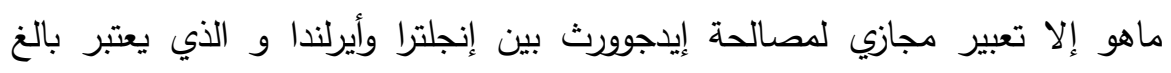

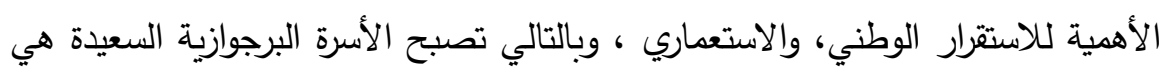

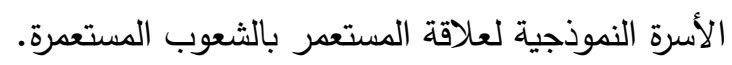

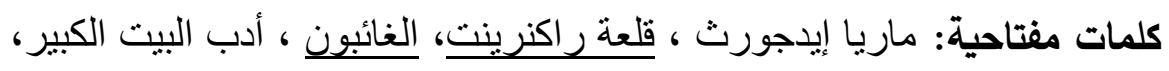
نظرية ما بعد الاستعمار. 


\section{A Postcolonial Representation of Maria Edgeworth's Castle Rackrent and The Absentee}

Dr.Hazmah Ali AI-Harshan

مجلة وادي النيل للاراسات والبحوث الإنسانية والاجتماعية والتربوية (مجلة علمية محكمة)

The relationship between historical context and fictional production has always been one of the distinctive features of Irish literature. The literary texts are often the product of history. There is a dialectic relationship between history and literary conception. The world of the text is interpreted in terms of Michel Foucault's concept of power, which emphasizes the association between the text and the political and social context that produces it. In Culture and Imperialism. Edward Said argues:

Within the nationalist revival, in Ireland and elsewhere, there are two distinct political moments, each with its own imaginative culture. ... The first was a pronounced awareness of European and Western culture as imperialism ... the second more openly liberalionalist movement occurred ... after World War Two. (270-271)

According to Edward Said, the first moment identifies the revival national identity and cultural resistance throughout the renewal of pre-colonial literary traditions and native languages. The first movement also involves the recovery of pre-colonial histories and geographies invaded by colonialism. Likewise, it entails the racial stereotypes of the colonizer's scale of superior/inferior, master/slave.

By the Act of Union of 1800, Ireland merged with Great Britain to form one United Kingdom. Historically, the Act of Union offered the concept of belonging to a larger imperial community which many Anglo-Irish found positive. Although Britain and France were at war until 1815, Ireland settled down to a period of peace. The most serious problem was the issue of land. The general despair of the Irish people could be traced almost entirely to the system by which their own native land had come to be occupied and owned, a system developed by centuries of conquests and disciplinary legislation. Anglo-Irish settlers had conflicting reactions to the Act of Union. Daniel Hack states:

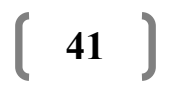


(ISSN : 2536 - 9555)

Thus, on the one hand, the Union formally integrated Ireland into Britain ... while on the other hand, it kept in place Ireland's separate, colonial administrative system. Rather than creating a true merging of national identities, the Union became (he focus of Catholic nationalism and only intensified the precarious "dual identity" of the Anglo-Irish or Protestant Ascendancy. (146)

The Big House tradition, a vital aspect in literature, symbolizes Irish history. It has haunted the imagination of many writers who portray houses that reflect moral and social significance. "Big House fiction is a reflection of, as well as a reflection on economic, social, and political change". Klaus Lubbers denotes. "Accordingly ... it has attracted both the literary critic and the historian" (17) Literary works trace the changing of the Big House in Ireland. Jacqueline Genet points out that the Big House "was the child of coquets, it was the victim of change. For most of the Irish people it symbolized oppression, yet it created the ambience within which Yeats flourished. That is its best epitaph" (28) However, the Big House is portrayed in the stories of individual families, and through the imagination of individual writers.

Coming from the Ascendance and reworkably associating with her father at an early age of her life. Maria Edgeworth wrote at the beginning of the nineteenth-century with an attitude that established her as a writer of the history of the Big-House and its future decline. The history of Anglo-Irish fiction begin with Edgcworth's novel a Castle Rackrent (1800). Silvia Fabre denotes that "Castle Rackrent is not only the first Irish novel, but also the first novel that deals with the theme of the Big House" (26). The novel has been read as a regional tale, a novel of place. James Cahalan points out that "Maria Edgcworth's historical importance" lies in the fact that she is "the originator of the regional novel" (18). The corruption of social, economic, and political conditions, Catholic emancipation, the dilemma of the peasant, the questions of landownership and absenteeism were all issues represented in

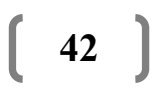




\section{A Postcolonial Representation of Maria Edgeworth's Castle Rackrent and The Absentee}

Dr.Hazmah Ali AI-Harshan

مجلة وادي النيل للاراسات والبحوث الإنسانية والاجتماعية والتربوية (مجلة علمية محكمة)

her novels of the period. Silvia Fabre claims that "[o]nce Maria Edgeworth opened the way for the Irish novel, 19th centurywriters began to explore the aesthetic possibilities that the subject of the landlord's house offered; from Romantic and Gothic perspectives." (28). However, every Irish writer identified that his picture of Ireland would be examined for its social, economic, and political overtones. Respectively, Edgeworth, as Carmen Rodríguez indicates, "was a pioneer in offering pictures of Ireland, which remained an unknown Other for many Britons." Though, "Edgeworth's desire was far from depicting Ireland as something unique, but rather, she aimed to show it as a place similar to England, and she addressed the Anglo-Irish, not the majority of the Irish population"(30).

It is worth considering Maria Edgeworth's family position as liberal Anglo-Irish landlords in late eighteenth-century Ireland. Marilyn Butler indicates that her father, Richard Lovell Edgeworth had returned to Ireland from England in 1782 "with a firm determination," in his words, "to dedicate the remainder of my life to the improvement of my estate, and to the education of my children; and farther, with the sincere hope of contributing to the melioration of the inhabitants of the country, from which I drew my subsistence" (qtd. in Hack 148). As for Maria, she worked as her father's assistant. Michael Hurst states that she became "something between a colonial civil servant and a missionary rescuing the masses from inferior material and spiritual practices" (123). It is important to identify that such a description underlines the colonialist assumption of English superiority. Ireland was not only a resource to be exploited, but the very source of the Edgeworth's "subsistence." They were dependent on those "inhabitants of the country" whom they sought to constitute ideologically. Edgeworth thus taught herself in the colonialist understanding of Ireland. She committed herself to her father's mission in several ways. Butler states that the educated herself through a course of reading about her new home, studying English 
(ISSN : 2536 - 9555)

"constitutional authorities" in addition to "Spenser and Sir John Davies, Arthur Young and Adam Smith"(qtd. in Hack 149).

At the same time, Edgeworth's duties on the estate brought her into contact with a number of her father's tenants and employees, and one especially important family retainer-John Langan- became the original inspiration for Thady Quirk, the storyteller of Castle Rackrent. Butler informs that Edgeworth "liked to entertain the family circle by mimicking[his] brogue and strange opinions"(qtd. in Hack 151). Langan is like Thady himself who is described in the Preface as roused from "his habitual laziness" and "persuaded to have [the story of the Rackrents] committed"(63). Indeed, Edgeworth transferred her colonial experience to paper. "At a domestic level, the Big House turns into an inferno of cruelty and continuous confrontations", as Silvia Fabre point out. "The negative characteristics of the Rackrents also extend into the public dimension of the Big House in another sense as the landlord doesn't fulfil has obligations, responsibly" (27). Edgeworth thus reveals some of the abuses that historically had been committed against the Irish working class by the managers whom English and Anglo- Irish landlords had used to work in then interests.

Castle Rackrent (1800) and The Absentee (1812) imply a colonialist mentality within the very categories of literary history moral and cultural values associated with Ireland in these novels most often appear negative ones. To Edgeworth Ireland and the Irish needed to be re- formed, and disciplined on English models, and so subjected in new ways to a more just English authority. Postcolonial theory figures as a means of analyzing the colonial relations within Castle Rackrent and The Absentee, and their contexts. B. Ashcroft, G.Griffths and H. Tiffin demonstrate:

Post-colonial theory involves discussion about experience ofvarious kinds, migration, slavery, suppression, resistance, represention. difference, races, gender, place, and responses to the influential master discourses of imperial Europe such

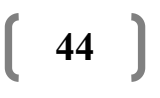




\section{A Postcolonial Representation of Maria Edgeworth's Castle Rackrent and The Absentee}

Dr.Hazmah Ali AI-Harshan

مجلة وادي النيل للاراسات والبحوث الإنسانية والاجتماعية والتربوية (مجلة علمية محكمة)

as history, philosophy and linguistics, and the fundamental experiences of speaking and writing by which all these come into being. (The Post-Colonial Studies 2)

These postcolonial tools examine the hegemony that has been suppressed within the texts, and explore the relations between a colonizing literature and its colonized subjects. In his book Orientalism, Said has effectively demonstrated that British imperialist projects in non-European places became sites for imaginative conquest as well as economic exploitation, that the two often worked together to merge a native English identity. From 1688.Martin Green claims that "England bad been expanding and the pride of Englishness had been swelling" (qtd. Mcinelly 54). Some colonies become the place of particular moral and cultural values as a result of merging with the British Empire. They were typically represented as different from an inferior to English ones.

Edgeworth's representation of the world of the Irish as other can be seen as a vital dimension of her colonial perspective Otherness rests on a duality. B.Ashcroft, G.Griffiths and H. Tiffin demonstrate that "colonized subject is characterized as 'other' through discourses such as primitivism as a means of establishing the binary separation of the colonizer and colonized and asserting the naturalness and primacy of the colonizing culture and world view" (The Empir Writes Back 169). On a cultural level, Edgeworth's Castle Rackrent and The Absentee make all nonEnglish Castle Rackrent lies in Edgeworth's characterization of the peculiarity of the other to her English reader; in the diversity between "Englishnes" and "Irishness." She represents her colonized Irish narrator, Thady Quirk, and his irresponsible masters in a situation of inferiority to the English readers. Castle Rackrent traces the progressive moral and physical degeneration of an Ascendancy family whose irresponsibility leads to their final ruin. Gerry Brookes indicates that "[ $[\mathrm{t}] \mathrm{hc}$ effect of Castle Rackrent is to provoke a peculiar combination of laughter at and pity for the 
(ISSN : 2536 - 9555)

predicament of these Irish landlords and their tenants" Simultaneously, "to make the reader see the causes of that predicament in the mental and moral confusion of the Irish, which is in trun caused by their own traits of character and encouraged by the degenerate social system they have inherited" (595). The ironic humor of the novel is a political device, which works to create the superiority of the domestic English reader over the native Irish subject. "Britishness was superimposed," as Linda Colley indicates, "over an array of internal differences in response to contact with the Other, and above all in response to conflict with the Other"(qtd. in Mcinelly 7). Colly hints that the British intensified a sense of national identity and seeing more oft themselves through their contact with colonized peoples. In this light, the only really "Irish" thing about Castle Rackrent is its subject matter.

The calculating mischievousness of Jason Quirk, the persona, in Castle Rackrent is the paramount example of Edgeworth's colonial otherness. The editorial device does not mention Jason and it never provides much guidance about Jason's character. Throughout the talc, Edgeworth condemns him as being the cunning, disloyal family retainer. The waste of the four Rackrent heirs who successively take possession of the castle reduce the family inheritance to nothing but debts. This critical situation is then exploited by Jason Quirk, Thad's son, a member of the catholic middle class, who becomes the main creditor of the estate with the purpose of becoming the owner or landlord. Edgeworth detests the decline of the traditional order, with the rise of somebody from the $t$ lower class to the status of landowner, and the more so being the "Irish." To her Jason is an usurper who comes in "usurp" the place of Sir Condy, although Sir Condy is a member of "a remote branch of the [Rackrent] family ... born to little or no fortune of his own" (85). We are told that Jason and Sir Condy attended grammar school together. Jason is "a good scholar from his birth" (74), and was "not a little useful to [Sir Candy] in his book learning," but Condy paid less attention to his schooling than to what he learned from Thady, who told him "stories of the

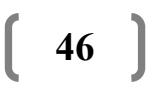




\section{A Postcolonial Representation of Maria Edgeworth's Castle Rackrent and The Absentee}

Dr.Hazmah Ali AI-Harshan

مجلة وادي النيل للاراسات والبحوث الإنسانية والاجتماعية والتربوية (مجلة علمية محكمة)

family and the blood from which he was sprung, and how he might look forward, if the then present man should die without childer, to being at the head of the Castle Rackrent estate" (85). While Sir Coadv "neglected to apply to the law" in anticipation of his inheritance (83), Jason completed the groundwork for his rise in the world by becoming first a clerk and then the agent for Sir Condy's ancestor, Sir Kit. Sir Condy's extravagance leads to his bankruptcy, when Jason became the possessor, he allowed Sir Condy to hand over the Rackrent estate. Jason treated Sir Condy with greater humanity and moderation than would any other possible buyer or creditor.

The reader is most likely troubled by the dilemma of how to evaluate the figure of Jason. Thady himself announces "Well, I was never so put to it in my life between ... my son and my master, and all 1 felt and thought just now, 1 could not upon my conscience tell which was the wrong from the right" (109). David Lloyd argues that the set of attributes that evidently typify the Irish nature can all be referred back to the particular stereotype of disloyalty, "and all leave the colonial power in a bog of uncertainty which the stereotype itself affirms" (qtd. in Hack 161-62). The reader's attitude will not resemble that of Edgeworth and the English reader's perspective. We come to agree with Gerry Brookes' view as he argues that Edgeworth makes the readers

think that the character of the Irish past and the remains of that past in the present render Irish landlords and their tenants particularly unfit to cope with the present, especially in the form of the self-aggrandizing cunning of a Jason Quirk, the middleman. On the other hand, Edgeworth shows that the Irish, self-destructive as they have been, are more colorful, eccentric, and interesting than those who take advantage of them and than the "British manufacturers" who may come after the Union to offer Ireland at least decent management. (594) 
(ISSN : 2536 - 9555)

Edgeworth's colonial altitude is clearly manifested. She uses Jason as an agent of the family's ruin and also to control the reader's attitudes toward the Rackrent family The passing of the old order with its limited virtues and astonishing peculiarity would be gone if one had any assurance that a better order than Jason would succeed it. Edgeworth holds out sonic hope in the end:

It is a problem of difficult solution to determine, whether an Union will hasten or retard die amelioration of this country. The few gentlemen of education, who now reside in this country, will resort to England, they are few, but they are in nothing inferior to men of the same rank in Great Britain. The best that can happen will be The introduction of British manufacturers in their places. (122)

These words, evidently, explain the patronizing role she has adopted. One looks down on the natives as ignorant and in need of the Englishmen to lead them on.

Edgeworth portrays Jason's Irishness as something dangerous which combines with his education to make him, or enable him to become, an Irish nationalist. In the figure of Jason, Castle Rackrent provides an early example of what will become a common imperialist dilemma. David Lloyd argues that "the extension of colonial hegemony requires the creation of an educated native elite without the guarantee that mastery of the instruments of domination assimilation" (qtd. in Hack 161). Castle Rackrent, then, arouse the reader's sense of threat. The English reader keeps looking anxiously to the Anglo-Irish to control the situation. Edgeworth constructs her narrative in such a way that the reader is made to laugh at and also to pity the Irish characters from a felt position of superiority.

The notion of making all non-English "others" subordinate to an English standard clearly functions in The Absentee. The reader's first perception of Lord Colambre comes through the eyes

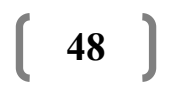




\section{A Postcolonial Representation of Maria Edgeworth's Castle Rackrent and The Absentee}

Dr.Hazmah Ali AI-Harshan

$$
\text { مجلة وادي النيل للاراسات والبحوث الإنسانية والاجتماعية والتربوية (مجلة علمية محكمة) }
$$

of some Englishwomen evaluating him as a marriage prospect: one describes him as "a very gentleman like looking young man," while the other remarks that he is "[n]ot an Irishman, I am sure, by his manner" (91), accordingly establishing the notion that lrishness and English decorum are contrary essentials. Edgeworth, then, declares a related divergence of English and Irish traits to generate her perception:

The sobriety of English good sense mixed most advantageously with Irish vivacity. English prudence governed, but did not extinguish, his Irish enthusiasm. But, in fact, English and Irish had not been invidiously contrasted in his mind ... he was not obvious to any of the commonplace ridicule thrown upon Hibernians; and he had lived with men who were too well informed and liberal to misjudge or depreciate a sister country. ... He had formed friendships in England; he was fully sensible of the superior comforts, refinement, and information, of English society; but his own country was endeared to him by early association, and a sense of duty and patriotism attached him to Ireland. (94)

Undoubtedly, the narrator emphasizes the idea of national differences as she describes the Irish as "vivacious" and the English as "rational." However. Edgeworth portrays Ireland as culturally inferior, lacking the "comforts, refinement, and information" of the English world. Colambre, then, has a double identity: an English one which is the mature fruit of a sophisticated education and an Irish one which is a product of "early association." Colambre as a consequence has a new identity and anew' cultural norm for Ireland, he is a hybrid-or occupies a "betweenness."

Colambre's parents, on the other hand, stand for the unpleasant traits of their native cultures. The Clonbronys turn out to be profligate, wasteful, and immoral. "Lady Clonbronys, in 
(ISSN : 2536 - 9555)

consequence of her residence in London, had become more of a fine lady ... [and] by giving splendid entertainment, at an enormous expense, made her way into a certain set off fashionable company." She becomes materialistic, ineffective and selfish as she seeks to achieve success by making sophisticated parties that she cannot pay for. As for Lord Clonbrony's suffering, we are told that "[s]ince he left Ireland, |he] had become less of a gentleman ... . Lord Clonbrony, who was somebody in Ireland, found himself nobody in England,a mere cipher in London"(113). Lord Clonbronys becomes "less of a gentleman," because of his attachment to a world $m$ which he has no tasks. He is "a mere cipher" who submissively forgives his wife's luxurious life and consumes the fortune of the family. Edgeworth attempts to condemn the Clonbronys as they, both morally and financially, precipitate their own ruin. Thus, Lord Colambre, as Meredith Cary indicates, "rescues his mother from the snobbish contempt ol English society, and his preference for administering his own estates from apposition of benevolent superiority repairs the family fortune" (30).

Language as a means of both oppression and opposition is a vital issue in postcolonial perspective. It employs obvious cultural and class differences. Gayatri Spivak has noted that "imperialism and its territorial and subject-constituting protect are a violent deconstruction of oppositions." ("Three Women's Texts" 268). This is to say that if the British evangelical mission abroad saw itself as bringing knowledge to non-Western people; it was because their cultures were perforce based on ignorance and superstition. However, rather than create cultures that perfectly emulated the British "model," imperialism instead brought together cultural differences-such as those pertaining to language-and forced them to combine. The colonized or the native is depicted as deprived of language. Anglo-Irish writers of the nineteenth created their work mainly for an English market. There was trouble about the linguistic otherness of the Irish who spoke Gaelic. Michael Neill explains that "the Irish novel of the nearly prt of the century ... nearly always comes to us with its footnotes or after notes packed

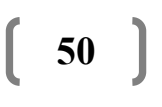




\section{A Postcolonial Representation of Maria Edgeworth's Castle Rackrent and The Absentee}

Dr.Hazmah Ali AI-Harshan

مجلة وادي النيل للاراسات والبحوث الإنسانية والاجتماعية والتربوية (مجلة علمية محكمة)

with details of regional explication" (83). Such reading gives a portrayal of the Irish as inferiors for their coloial masters. In fact "English" and "Irish" languages constitute mutual relations. Without the presence of the one there would be no call for the constant reassertion of the other's superiority. However, Edgeworth's Englishness in Castle Rackrent and The Absentee clearly a function of a linguistic sophistication that takes the other' language as a mere joke.

The very ground of Castle Rackrent is, accordingly, its dependence on English for its articulation. The Preface to the novel is undertaken by Edgeworth's editorial persona in the familiar eighteenth-century mode. She notifies that Thady Quirk's simple style is not elevated and also needs refinement, explanatory notes, and a glossary. The Irish Thady Quirk is a fictitious, poor, aged retainer who provides the intimate biography of "the family." Thady's storytelling is related to an oral tradition Through the Preface, he is implicitly represented as one of "those, who. without sagacity to discriminate character, without elegance of style to relieve the tediousness of narrative, without enlargement of mind to draw any conclusions from the facts they relate, simply pour forth anecdotes and retail conversations, with all the minute prolixity of a gossip in a country town"(62). At the same time as Toady's "careless conversations" and "half-finished sentences" were earlier quoted in the Preface as the linguistic substance that constructs "the characters of men," (61) they have no importance. Thady Quirk's account hence requires the correction of the enlightened colonialist perspective. He falls short of recognizing the clearly ridiculous habits and manners of many of his masters, resorting instead to a blind obedience to them; he lacks the acuteness to sec through the deficiencies or those whom he serves.

Edgeworth's attempt is to correct the tone, accent, and idiom of the "other" (Irish), and to put them to a mixture of economic, political, and literary applications. She, as the editor, 
(ISSN : 2536 - 9555)

doubts that "Thady's idiom," native's inaccuracy. They need Edgeworth's colonial knowledge to meet the English reader's standards. As the editor denotes that English readers "will want no evidence of the truth of honest. Thady's narrative," to "those who are totally unacquainted with Ireland, the following Memoirs will perhaps be scarcely intelligible, or probably they may appear perfectly incredible" (62-63). The recognized otherness of "Thady's idiom," represented by the editor as the authentic language of the Irish peasant, obliges her lo supply "ignorant English readers" (63) with interpretive aids (notes, a preface, and a glossary). So the superiorEnglish readers might be able to form a proper reading of their own native inferiors. Edgeworth assumes that the linguistic inferiority of the Irish confuses the interpretive process accepted by English readers. Thus the narrative voices of Castle Rackrent in Colin Graham's words, "counterpoise an editorial presence, established as rational, professional, and English against that of the oral, premodem, and 'racially' different Thady" (24).

Despite Edgcworth's attitude, the Irish Thady Quirk is an imperative element in providing the detailed biography of the Rackrentfamily. Some critics, like Silvia Fabre, underline Thady Quirk's importance. Silvia argues that "Thady Quirk plays a key role in telling the story because be is both a participant and witness to the facts that the relays. In this way Thady Quirk opens the doors of the Big Mouse to us ... . The reader becomes aware of how the heirs of Castle Rackrent live" (26). Actually, Edgeworth reveals her own colonial position when she seeks to produce the colonized for the colonizer, and to create her own authority. "On the surface," as Kerstin Fes argues "it seems as if Edgeworth is setting up a clear binary opposition between Thady's 'Irish' emotional and subjective narrative and the Editor's 'English' dispassionate and objective contribution"(376). She attempts to change the relations between colonized and colonizer. He clearly has no name at all until his English author gives him one; thus he possesses the authority only as given to him. Being the editor, 


\section{A Postcolonial Representation of Maria Edgeworth's Castle Rackrent and The Absentee}

Dr.Hazmah Ali AI-Harshan

مجلة وادي النيل للاراسات والبحوث الإنسانية والاجتماعية والتربوية (مجلة علمية محكمة)

Edgeworth destabilized Thady's authority as narrator of the tale in order to protect her own.

Likewise, language dimension plays an essential role in The Absentee. Julia Miller proclaims that "[t]he impulse to counter accusations of Irish barbarity causes," Edgeworth "to construct mirror-image positive stereotypes of Irish refinement. These romantic stereotypes coexist beside an almost journalistic documentation of the poor in Maria Edgeworths" (17). One of these positive stereotypes of Irishrefinement is the selection of names. "In the Anglo-Irish gentry's scramble for political positioning after the Union," Miller adds "one's name identified one's affiliation with post rebellion winners and losers, now tensely mingling in early nineteenth-century Dublin and London." Edgeworth's heroine's name, Grace Nugent, is connected mythically with"that 'Grace Nugent's the name of Act, of Union, a famous poem by Irish bard Torlough Carolan (1670-1738)" (19).

The linguistic characterization of the Grace Nugent persona revealed Edgeworth's implicit colonial attitude. Nugent is a mute person who seldom speaks. We are told that "Miss Nugent said everything he wished lo have said, and with all the propriety and delicacy with which he thought he could not have spoken ... she seemed so intent upon others as totally to forget herself" (103). Furthermore, Grace Nugent is deprived of dialogue. On one occasion, Colambre and his mother talk about the attractiveness of Miss Broadhurst, the conversation is broken up to bringGrace's voiceless opinions: "The unconscious Grace Nugent now made a warm eulogium of miss Bniadhurst's sense, and wit, and independence of character." Once she expresses herself in reaction to Colambre's annoyance of Miss Broadhurst, Grace says; "[Miss Broadhurst] is, I assure you. a friend of mine; and, as a proof. I will not praise her at this moment I will go farther mil -1 will promise that I never will praise her to you till you begin to praise her to me" (115). Unlike, Lady Uonhrony. Grace Nugent displays intelligence, 
(ISSN : 2536 - 9555)

perfect conduct, and moral strength. Miller argues that "Grace Nugent is not the first reticent heroine Edgeworth produced. In fact, she exemplifies a type of heroine that Julie Shaffer identifies as "'the perfect heroine,' a Pamela-like figure who demonstrates moral autonomy and unwavering virtue under pressure" (20). Observably, Edgeworth attempts to idealize her Irish heroine. Yet this image of idealization can be seen as a kind of suppression that resembles the Irish culture image of containment. Miller stales that "Edgeworth creates a static, romantic Irish heroine who stands in for the more threatening elements of the native Irish (Catholic) population" (21).

However, in the final section of The Absentee there is a linguistic modification taken with "first-person dialed in which Larry Brady, afaithful servant of the Colambres, describes the idyllic reunion of the Irish tenants with their true and rightful landlords" (Miller 29-30). Brady's attitude is opposite to Grace Nugent's silence and muteness. She expresses her happy feelings as she says: "[t] master's come home, long life to him! And family come home yesterday, all entirely! The ould lord and the young lord (ay, there's the man. Paddy!) and my lady, and miss Nugent"(375). We might say that in the course of the linguistic narrative of The Absentee, Edgeworth struggles to imagine reconciliation between colonialism and rebellious Ireland. She modifies political purposely as a familial plot. Miller states that the novel portrays "a courtship and marriage between an English or Anglo-Irish suitor and an Irish heroine. In both cases, the Irish heroine stands in for nation, and the true romance occurs between the English/Anglo- Irish suitor and the Irish nation he comes to know" (13). Consequently the imperial marriage in The Absentee works hegemaonically to produce the domesticity to colonial stability.

Edgeworth's attitude towards the social disorder is a further verification of the colonizer's mentality. Patriarchal deficiency plays a vital role in Castle Rackrent. The rowdy transmission of family property in the novel docs not overtake arranged patriarchal manner. James Newcomer states that Edgeworth "has the 


\section{A Postcolonial Representation of Maria Edgeworth's Castle Rackrent and The Absentee}

Dr.Hazmah Ali AI-Harshan

مجلة وادي النيل للاراسات والبحوث الإنسانية والاجتماعية والتربوية (مجلة علمية محكمة)

philosophical purpose of making a sociological judgment on the family and a moral judgment on the individual members of the family" (171). It indicates what Edgeworth believes in as trouble in the social order among the Anglo-Irish. It provides evidence of English prejudice against Irish Catholicism. We are told in Castle Rackrent that Sir Patrick O'Shaughlin must "take and bear the surname and arms of Rackrent ... by Act of Parliament" (66) so as to take over owing to the Penal Laws, which forbids Catholic ownership of property. The drunken Sir Patrick gives up his religion and his family name in order to guard his estate and pass it to his son. Sir Murtagh who exploits his tenants and produces no heir. Sir Kit, who is Murtagh's younger brother, inherits and misuses his estate. Finally, the estate passes to Sir Condy, the "heir-at-law [who belongs to] ... a remote branch of the family" (85). However, the disorder in the transmission estate shows the social instability of the system. The Rackrent men inherit only by the right of being a male Protestant descent. We observe the absence of the female heirs in the generation of male heirs.

The hierarchy of structural gendered inequalities is another concern of postcolonial theorists. Edgeworth's novels include the secondary questions which relate to the gender issue. In her essay "Can the Subaltern Speak?" Spivak argues that the imperialist and racist biases of colonial text coexist at the same time with the questioning of dominant imaginings of masculinity, and males as representative of patriarchal values. She notes:

Within the effaced itinerary of the subaltern subject, the track of sexual difference is doubly effected. The question is ... [t]hat the ideological construction of gender keeps the male dominant. If, in the context of colonial production, the subaltern has no history and cannot speak, the subaltern as female is even more deeply in shadow. (28) 
(ISSN : 2536 - 9555)

R Selden, P. Widdowson, and P. Brooker pinpoint that the "figure of the 'subaltern' [is] an important category in Spivak's writings." It is used "to refer to those of inferior rank without class consciousness." The "colonized non-elite," in Spivak's usage, cannot speak. That is to say, the oppressed and silenced cannot, by definition, speak or achieve self-legitimation without ceasing to be that named subject under neo-colonialism."(224). Recently, Spivak has pointed out that the tendency tocreate an insider/outsider opposition in order to theorize sexual differencefrequently leads theorists to privilege issues of gender in politicalcritiques. She argues that gender seems the irreducible distinction among people, and the issues of cultural differences among women become absorbed in the address of sexual imbalance (In Other Worlds 262). In "The Other Question," Homi Bhabha also accounts for the durability of seemingly fixed cultural identities as "the excess" of signification of "the other." He notes how the oppositions used to distinguish "others" from the dominant culture serve a stabilizing function: they seem to reify, confirm, and maintain the alien sense of "the other" (18-37). This notion of "excess" is especially useful here in reading Edgeworth's Castle Rackrent and The Absentee as the stories of the powerless women. If we grant that "the other" exists outside of the historical precedents for signification, then woman, as a category independent of class and heritage occupies the space of the other. Bhabha also suggests that "otherness" is an identifiable site of difference. It is not that the powerless woman has her own identity, but rather that she has not yet been expressed within the dominant discourse.

Castle Rackrent and The Absentee apparent oppositions encourage the claim that Edgeworth's female characters find recourse to power through resistance. Edgeworth reveals the processes through which thesewomen come to struggle for identity. She discloses her own position as a female narrator. Her control over narrative design of her female characters reveals her insight into the insufficiency of predicable and gendered definitions. She asserts the entanglements of influences in constructing the stories 


\section{A Postcolonial Representation of Maria Edgeworth's Castle Rackrent and The Absentee}

Dr.Hazmah Ali AI-Harshan

$$
\text { مجلة وادي النيل للاراسات والبحوث الإنسانية والاجتماعية والتربوية (مجلة علمية محكمة) }
$$

of her females' lives. Implicitly, she challenges the social and ideological patriarchy.

The issues of gender and cultural difference construct conflicting elements of oppression within power relations in Castle Rackrent. Edgeworth, as the representative of the colonial woman writer, asserts the doubleness of power relations in this crosscultural encounter. The Rackrent women are subject to patriarchal colonial rule, yet they are doubly positioned as powerful and powerless. The female figures in the novel experience an aggressive patriarchal abuse of supremacy. "Marriages are central to the narratives of Castle Rackrent," as Colin Graham states. "Yet the text itself delineates a succession of failing marriages" (22-23). Rackrent marriages, essentially, are made for money, not for love. As women fail to produce an heir, they are basically used by their husbands as means of entrance to property. Munagh chooses his wife, for example, on the basis of the fortune she may bring. We are told that he "looked to the great Skinflint estate" (68) as a means of enhancing his own purse. Sir Kit also marries" the grandest heiress in England" (75) to revive the family wealth. When she refuses to give him her costly diamond, he locks her in her bedroom for seven years, and she is freed only at his death. Kit's wife is thus caused to experience a patriarchal authority. She suffers most because of her racial difference; "she was a Jewish," a "heretic Blackamore" of "dark complexion." Thady's anti-semitic tone shows him to be "greatly shocked" to discover that "she was little better than a blackmoor." Her looks, her habits, her refusal to eat pork, and her talk attract Thady's d disdain. He comments: "never a word [Kit's wife] answered, so I concluded she could not speak a word of English, and was from foreign parts" (76). On one occasion she asks her husband about an Irish term that Thady uses, whom defines her deficience of knowledge as "ignorance." She is calling a bog "a very ugly prospect" and seeing Irish "trees" as equivalent to English "shrub." Thady says: "[to]| hear her talk, one might have taken her for an innocent" (77) Thady looks upon "the 
(ISSN : 2536 - 9555)

Jewish" as his inferior and other, and in that way be takes up a place of power of which he was deprived.

Ironically, Thady himself is treated as substandard by "the Jewish" lady. Like the native English nobility, she displays her discrimination regarding the language of the other; she treats Thady's dialogue with scorn. We are told that at hearing the story of the bog, "the Jewish ... fell to language like one out of their right mind, and made me say the name of the bog over for her to get it by heart a dozen times-- then she must ask me how spell it, and what was the is meaning of it in English" (78). Thady and "the Jewish" therefore have equally doubled positions: each could function as an echo for the other. The Jewish's racial "otherness", to English and Irish identity, makes her subject to Thady's aloofness as he is to hers. Still both of them are marginal characters in Edgeworth's conception. The Jew and Thady, in Daniel Hack's words, "are linked within a scale that structures them ... as outsiders yet pits them simultanceously against one another" (157). Similar to Edgeworth herself, Thady and "the Jewish" lady recognize the other's otherness as inferiority. They are unable to observe their own subordination to English patriarchal rule. It might be argued that Thady and "the Jew" appear as Edgeworth's own implicit place as a colonial woman writer exposed to the patriarchal colonial discourse. Edgeworth's identification with them as dominant power gives her the chance to impose the hegemonic English standard with which she identifies.

Nevertheless the female figures in Castle Rackrent are not victims. Silvia Fabre points out that the ruined females have "to fight in order to maintain any dignity or to preserve [their] personal wealth" (28). They defy their husbands' power and subordination. On the one hand, they refuse to be subjected by their husbands and reject their natural reproductive role as they remain childless. On the other hand, they make material income and show an inclination for wealth; they do not display devotion to neither the estate nor their husbands. Murtagh's wife is ambitious and constructs a charity school only so her duty-yarn may be spun gratis by its

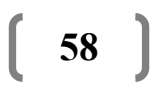




\section{A Postcolonial Representation of Maria Edgeworth's Castle Rackrent and The Absentee}

Dr.Hazmah Ali AI-Harshan

$$
\text { مجلة وادي النيل للاراسات والبحوث الإنسانية والاجتماعية والتربوية (مجلة علمية محكمة) }
$$

pupils. Kit's wife also exposed to patriarchal power, yet she resists and struggles to prove her right of her own property. Regardless of her powerlessness to her husband, and Thady's marginalizing of her as a "blackmoor,", "the Jew" is not totally without power. Her race marks her as not English, but her command of the English language and her scornfulness of the Irish make her parallel the colonizer.

Patriarchy as a heal for the disordered Irish society also materializes in The Absentee. Edgeworth claims "an Irish estate and Irish tenantry may be degraded in the absence of those whose duty and interest it is to reside Ireland, to uphold justice by example and authority; but who, neglecting this duly, commit power to bad hands and bad hearts--- abandon their tenantry to oppression, and their property to ruin"(50). According to colonial perspective, the remedy of Ireland relies on the presence of the legitimating masculine as a patriarchal figure. His presence is an essential part of the therapy for a disordered society. Accordingly, Colambre comes back to Ireland due to the ruin in his father's financial affairs. He would identify that the "duty and interest," good management and rule of his tenants depends upon bringing back the father's right place. It is due to his parents' mutual irresponsibility that the crisis happened. We are told that he was "determined that he would see and judge of that country for himself, and decide whether his mother's dislike to residing there was founded cm caprice or on reasonable causes" (169). He conceals his true identity as "he might see and hear more than he could as heir apparent to the estate" (218). He first visits the town that bears his name (Colambre). He finds a model estate which is run by a good agent; it is "improved, and fostered, and made" (220) by the Burke who treats the tenants, in good way and develops the conditions of estate in spite of its owner's apathy. The condition of the other estate is not good; it is ruled over by the bad agent Garraghty. On townsman, and a tenant on the Clonbrony estate maintain that Lord Clonbrony "might as well be West India planter, and we negroes, for anything he knows to the 
(ISSN : 2536 - 9555)

contrary"(219). Garraghty, the agent, even charges. Clonbrony “ because he is absent ... it would not be so was he prisint"(234). Subsequent to this visit, Colambre comes to the conclusion that the therapy of the situation depends on the rehabilitation of his parents, conforming them to patriarchal gender ideals, which will lead to restoration of the estates.

The gendered culture of patriarchal task and feminine submission is established in The Absentee. We are told that lady Clonbrony finds trouble in coming back to Ireland: "Til never hear of leaving Lon'on--- ther's on living out of Lon'on--- I can't, I won't live out of Lon'on, I say", yet Colambre begs " her natural feelings, which though smothered, he could not believe were wholly extinguished" (288). Colambre's mission is based on fitting his father and mother in their proper hierarchy of structural gendered inequalities. In other words, he wants his father to adopt the patriarchal power and his mother to surrender to his patriarchy. He says:

O mother ... throwing himself at lady Clonbrony's feet, restore my father to himself! Should such feelings be wasted?---No; give them again to expand in benevolent, in kind, useful actions ; give him again to his tenantry, his duties, his country, his home; return to that home yourself, dear mother! Leave all the nonsense of high life---scorn the impertinence of these dictators of fashion. (290)

The only way to "restore" Lord Clonbrony "to himself" lies in his wife's hands, and her yielding to return to Ireland which makes possible his re-establishment of power and authority. Implicitly the colonial notion here is that Ireland necessitates this patriarchal masculine presence not England. The preservation of an ordered English society and the improvement of a disorderly Irish society figures noticeably. A stable familial order guarantees the imperial mission in Ireland. 


\section{A Postcolonial Representation of Maria Edgeworth's Castle Rackrent and The Absentee}

Dr.Hazmah Ali AI-Harshan

مجلة وادي النيل للاراسات والبحوث الإنسانية والاجتماعية والتربوية (مجلة علمية محكمة)

In a patriarchal society, gender is conflated with sex, culture with nature, masculinity with intellectual and physical power, energy and creativity, and femininity with receptivity, passivity, and a low level of intellectual and imaginative ability. Edgeworth demonstrates the uneasiness many nineteenth-century literary women felt about literary production and literary authority. Castle Rackrent marked Edgeworth's first literary attempt. It was written without her father's guidance. She proclaims her dependence on her father's assistance in producing her literary works probably to avoid the offence of patriarchal authority. This leads us to consider her choice of Irish narrator, Thady to produce her text. Edgeworth, as a colonial woman writer, assigns herself the power to represent Thady's idioms to the English readers. This mutual dependence, thus, makes Thady an agent of her literary identity. As for The Absentee, it represents the proper familial relationship as a vital aspect of domesticity. It is one of the dominant themes of the nineteenth-century fiction. Zelda Austen states that "the extreme poles of courtship marriage, and children on the one hand or disgrace, suffering, and death one the other hand" (552) characterize the writings of many nineteenth-century literary women. Thus, the Edgeworth's preference of the familial perspective is an attempt to reassure her literary authority. We might say for her as for others, the norms of gender make any act of writing potentially threatening to the culturally constructed "feminine" self.

Edgeworth's position is paradoxical for she is the colonizer in the texts she creates, at the same time she is part of the gender issue that falls under postcolonial discourse. This view leads us to consider Homi Bhabha's observation that "it is difficult to conceive of the process of subjugation as a placing within orientalist or colonial discourse for the dominated subject without the dominant being strategically placed within it too"(25). In other words those who subject are also subjected. As a woman, Edgeworth does not have the power to vote in English/Irish 
(ISSN : 2536 - 9555)

parliaments. Such elimination from participation in colonial rule distances Anglo-Irish women writers from the overall protect of colonization. This is not to suggest that Edgeworth was a natural opponent of the colonization of Ireland. To a certain extent, the female artist's powerlessness to enjoy the colonial law distorted her relationship to that imperialist project. It might be said that even the colonizing Edgeworth is also a member in "the process of subjugation," which takes place in terms of gender differences.

To conclude, the present study has revealed the geographical 'Other' placed by Edgeworth to her English readers in a position of inferiority to emphasize the gap between the Englishness and Irishness. The significance of Castle Rackrent lies mainly in considering it as the first English novel to speak in the voice of the colonized Irish. Her satirical tone is political, it works to create and protect the superiority of the domestic English reader over the Irish subject. The Absentee functions as an imperial plot. The reconciliation of England and Ireland is seen in the marriage of the Anglo-Irish (Colambre) with the Irish (Grace Nugent), and the happy bourgeois family consequently becomes the model for colonizer-colonized relationships. Finally, the novel works hegemonically to produce the domestic stability considered so crucial to national and colonial stability.

\section{References}

Ashcroft, Bill, Gareth Griffiths, and Helen Tiffin, eds The Empire Writes Back Theory and Practice in Post-colonial Literatures. London: Routledge, 1989.

---, eds. The Post-Colonial Studies Reader. London: Routledge,1995.

Austen, Zelda. "Why Feminist Critics Are Angry with George Eliot." College English 37.6 (1976):549-61.

Bhabha, Homi K. "The Other Question" Screen 26 (1983): 1837.

Brookes. Gerry H. "The Didacticism of Edgeworth's Castle Rackrent" Studies in English literature (Rice) 17 (Autumn 77):593. 


\section{A Postcolonial Representation of Maria Edgeworth's Castle Rackrent and The Absentee}

Dr.Hazmah Ali AI-Harshan

مجلة وادي النيل للاراسات والبحوث الإنسانية والاجتماعية والتربوية (مجلة علمية محكمة)

Cahalan. James M. The Irish Novel: A Critical History. Dublin: Gill and Macmillan, 1988.

Cary. Meredith. "Privileged Assimilation: Maria Edgeworth's Hope for the Ascendancy." Eire-Ireland: A Journal of Irish Studies 26(Winter 1991): 29-37.

Edgeworth, Maria. Castle Rackrent. 1800. London: Oxford UP. 1984. ---. The Absentee. 1812. Oxford: Oxford UP. 1988.

Fabre, Silvia Diez. "The After-Effects of Maria Edgeworth's Castle Rackrent on Some Twentieth Century female Irish Novelists." British and American Studies (1998): 25-33.

Fernández-Rodríguez, Carmen María. "Cannot an Irishman be a good man?" Maria Edgeworth's "The Limerick Gloves" (1804) as a Tale of Irish Identity." Estudios Irlandeses, Issue 15,( March 2020-Feb. 2021): 26-38. ISSN 1699-311X.

Fest, Kerstin. “Maria Edgeworth, Castle Rackrent (1800).”In Handbook of British Romanticism. Ed. Ralf Haekel: De Gruyter P, 2017: 376-390.

Graham, Colin. "History, Gender and the Colonial Moment: Castle Rackrent." Irish studies review 14(Spring 1996): 21-24

Hack, Daniel. "Inter-nationalism: Castle Rackrent: and Anglo-Irish Union.” Novel: A Forum on Fiction 29 (Winter): 145.

Hurst, Michael. Maria Edgeworth and the Public Scene. Coral Gables: U of Miami P. 1969.

Jacqueline, Genet, ed. The Big House in Ireland: Reality and Representation. USA: Barnes \& Noble Books, 1991.

1ubbers, Klaus. "Continuity and Change in Irish Fiction: The Case of the Big House Novel." Ancestral Voices the Big House in Anglo-Irish Literature. A Collection of Interpretations. Dublin Lilliput P, 1992.

Mcinelly, Brett. "Epanding Empire, Expanding selves: Colonialism the novel, and Robinsons Crusoe." Studies in the Novel. 35(Spring 2003):112 
مجلة وادي النيل للاراسات والبحوث الإنسانية والاجتماعية والتربوية (مجلة علمية محكمة)

(ISSN : 2536 - 9555)

Miller, Julia Anne. “ Acts of Union: Family Violence and National Courtship in Maria Edgeworth's The Absentee and Sydney Owenson's The Wild Irish Girl" Border crossing: Irish womenWriters and National Identities . Tuscaloosa: U of Alabama P, 2000:305.

Neill. Michael. "Mantles, Quirks, and Irish Bulls: Ironic Guise and Colonial Subjectivity in Maria Edgeworths Castle Rackcrent." Review of $\begin{array}{lllll}\text { English } & \text { Studies } & 52 & \text { (Feb } & \end{array}$ Newcomer, James. "Castle Rackrent : Its Structure and Its Irony." A Quarterly for Literature and the Arts (Detroit, MI) 8 (966): 170-79.

Rauchbauer, Otto, ed. Ancestral Voices the Big House in Anglo-Irish Literature: A Collection Of Interpretations. Dublin: Lilliput P.1992.

Said. Edward. Orientalism. New York: Vintage, 1979.

—. Culture and Imperialism. New York: Knopf, 1993.

Selden, Raman , Widdowson, Peter and Brooker. Peter. A Reader's Guide to Contemporary Literary Theory. London: Pearson, Longman, 2005.

Spivak, Gayatri Chakravorty . "Can the Subaltern Speak?" The PostColonial Studies Reader. Eds Bill Ashcrott, Gareth Griffiths, and Helen Tiffin London: Routledge, 1995.

--- . In Other Worlds. New York: Methuen, 1987.

--- . "Three Women's Texts and a Critique of Imperialism." In Race, Writing, and Difference. Ed Henry Louis Gates, Jr. Chicago: U of Chicago P, 1986.

William, Patrick and Liura ,Cbrisman, ,eds. Colonial Discourse and Post- Colonial Theory: A Reader New York : Harvester Whcatsheaf, 1994. 